\title{
The Theological Sense of the Polish Antiphons: The Song and the Hymn from the Mass of the Lord's Supper
}

\author{
Bartosz Zygmunt (D)
}

check for updates

Citation: Zygmunt, Bartosz. 2021. The Theological Sense of the Polish Antiphons: The Song and the Hymn from the Mass of the Lord's Supper. Religions 12: 169. https://doi.org/ $10.3390 /$ rel12030169

Academic Editor: Edward Foley

Received: 26 January 2021

Accepted: 3 March 2021

Published: 5 March 2021

Publisher's Note: MDPI stays neutral with regard to jurisdictional claims in published maps and institutional affiliations.

Copyright: (C) 2021 by the author. Licensee MDPI, Basel, Switzerland. This article is an open access article distributed under the terms and conditions of the Creative Commons Attribution (CC BY) license (https:// creativecommons.org/licenses/by/ $4.0 /)$.
Faculty of Theology, University of Silesia in Katowice, 40-043 Katowice, Poland; bartosz.zygmunt@us.edu.pl

\begin{abstract}
The Eucharist, a gift of God's fatherly love, is the heart of the Church life. It constitutes the most important reality, but also a sacrament of everyday life. Awareness of that great gift leads to a deep need for gaining an insight into the beginnings of the Eucharist—-the Mass of the Lord's Supper. The aim of the present article is to investigate the theological content of the antiphons, the song, and the hymn included in the contemporary Polish Roman Missal. The Author will present a theological analysis of the Polish antiphons, the song, and the hymn from the Mass of the Lord's Supper in the chronological order of their appearance in the contemporary liturgy. The texts will be subject to historical and linguistic analysis. The texts of the antiphons are rooted in the Bible. For that reason they will be first analyzed from the historical point of view, and then juxtaposed with the version from the Millennium Bible and with the original Greek text, in order to identify differences and analogies between them. Next, the texts will be analyzed from the linguistic and pragmatic perspective. The consideration will end with a short summary of the sources and theological motifs identified in the course of the analysis.
\end{abstract}

Keywords: Eucharist; Lord's Supper; antiphons

\section{Introduction}

The Eucharist - a gift of God's fatherly love-lies in the heart of the life of the Church. It is the most important reality, but at the same time, the sacrament of everyday life-a realization of the best desires of the human heart. In the Eucharist we worship God, but at the same time, it reveals before people the truth about themselves. The Eucharist is the source and summit of the Christian life. It constitutes such a great good for the Church that we cannot expect any greater gift from God ${ }^{1}$. Eucharist is a great mystery! It is a mystery that must be appropriately celebrated ${ }^{2}$.

Realizing how great that gift is leads us to a deep need for examining the origins of the Eucharist in the Mass of the Lord's Supper. The aim of the present paper is the analysis of the theological sense of the antiphons, the song, and the hymn from that Mass formulary in the contemporary Roman Missal. Despite the existence of numerous works on the Paschal Triduum and the Easter Vigil, the question of the theological content of the Coena Domini mass seems to require further investigations.

The article contains the theological analysis of the Polish antiphons, the song, and the hymn from the Mass of the Lord's Supper. The analysis is conducted in the chronological way, in line with the order of those texts in the contemporary liturgy. The examination of the texts is based on the historical-critical method ${ }^{3}$ and the linguistic method ${ }^{4}$.

The liturgical text, which is often rooted in the Bible, constitutes a form of linguistic expression, just like any literary text, whose author wants to communicate a specific message

1 Cf. B. Nadolski (2011), Liturgika, vol. 4: Eucharystia, Poznań, p. 3.

2 Cf. John Paul II (2004), Apostolic letter Mane nobiscum Domine (7.10), 17, in: http:/ /www.vatican.va/content/john-paul-ii/en/apost_letters/2004 /documents/hf_jp-ii_apl_20041008_mane-nobiscum-domine.html (accessed on 15 December 2020).

3 J. Czerski (2012), The Methodology of the New Testament, Opole, p. 89.

4 Cf. A. Żądło (2002), Eklejzalny wymiar kolekt adwentu w Mszale Rzymskim Pawła VI. Studium teologiczno-lingzwistyczne, Kraków, pp. 9-14. 
to the reader, using the appropriate linguistic structures. The process of communication between the author of the text and its recipient is analyzed with the linguistic method. It is one of the literary methods of analyzing texts of the New Testament. It belongs to the group of methods, which analyze a given text synchronically, as a complete and coherent literary unit. Synchronic analysis is not interested in the origins of the text. The linguistic method studies texts in three consequent stages: (1) syntactic analysis; (2) semantic analysis; (3) pragmatic analysis. ${ }^{5}$

The analysis of biblical texts with the linguistic method focuses on finding answers to the question about what message the author passes to the readers. Unfortunately, the linguistic method neglects the whole historical process of text creation, including the author's and the readers' background, as well as the situations in which the book was written. However, taking those aspects into account while analyzing texts often becomes indispensable. In order to meet those needs the historical-critical method was developed. It allows scholars to include the historical aspect of the text in their analysis. The historicalcritical $^{6}$ analysis is "historical" because it provides a historical perspective on biblical texts, but it is also "critical" because it uses a set of objective rules and activities, which contribute to the accurate analysis of texts and understanding of their sense. Thus, the historical-critical method is based on critical observations and it allows us to discover the origins and history of a text and its specific elements ${ }^{7}$. That is something particularly important when it comes to studying texts coming from the Gospels as their genesis was a long process ${ }^{8}$. The historical-critical method of analysis encompasses four stages. They are: (1) literary criticism; (2) form criticism (Formgeschichte); (3) tradition criticism; (4) textual criticism $^{9}$.

The antiphons are rooted in the Bible, and for that reason we will start with the historical-critical method. Next, they will be confronted with the Millennium Bible in order to identify differences and analogies with the biblical source, and with the original Greek text ${ }^{10}$. After that, the texts will be analyzed with the linguistic method (the syntacticsemantic analysis and the pragmatic analysis).

The texts of the song and of the hymn, which only allude to Scripture, will not be confronted with the biblical texts for the sake of their length.

The article ends with a short summary concerning the examined sources and the theological content identified during our analysis.

\section{Analysis}

Now, we will analyze all the Polish antiphons, the song, and the hymn, which are included in the formulary of the Mass of the Lord's Supper celebrated on Maundy Thursday. All the texts come from the 2013 Mszat rzymski dla diecezji polskich ${ }^{11}$.

The analysis will be conducted in three stages: (1) historical-critical analysis, (2) syntactic-semantic analysis (the linguistic method), and pragmatic analysis (the linguistic method $)^{12}$. For the linguistic analysis we will confront three versions of the text, coming

J. Czerski (2012), The Methodology of the New Testament, Opole, p. 65.

Cf. H. J. Sobeczko (2007), Pluralizm metod stosowanych w nauce o liturgii, Studia Nauk Teologicznych 2, p. 259.

Cf. A. Durak (1999), Metody hermeneutyczne w twórczości homiletycznej, Seminare. Poszukiwania naukowe 15, p. 78.

Ibid., p. 89

J. Czerski (1997), Metody interpretacji Nowego Testamentu, Opolska Biblioteka Teologiczna 21, p. 69.

10 Comparing the texts of the antiphons with their original Greek version from the Bible complies with the instruction of Congregation for Divine Worship and the Discipline of the Sacraments (2001) Liturgiam authenticam of 28 March 2001, where in point 24 we read that the liturgical texts ought to be translated directly from the original versions, that is from Latin when it comes to the texts of ecclesiastical composition, and from Hebrew, Aramaic, or Greek in the case of biblical texts.

11 Cf. Holy See (2013), Mszat rzymski dla diecezji polskich, Poznań, pp. 126-32.

12 Cf. A. Żąłło (2002), Eklejzalny Wymiar Kolekt Adwentu w Mszale Rzymskim Pawła VI. Studium Teologiczno-Lingwistyczne, pp. 9-14. 
from: $1 . \mathrm{MR}^{13}$, 2. The Millennium Bible (Biblia Tysiaclecia) ${ }^{14}$, 3. The Greek-Polish New Testament (Grecko-polski Nowy Testament) (including grammar codes and literal translation) ${ }^{15}$.

In order to indicate the differences between the texts we will use the following rules: words highlighted in grey are unique as they appear only in that version of the text; words that are underlined and preceded by superscript containing a lower-case letter indicate pairs of words from the antiphon (hereafter abbreviated as ANT) and the Millennium Bible (hereafter abbreviated as MB); words in bold, followed by superscript containing a capital letter illustrate parallelisms between MB and the literal translation (LT).

\section{The Entrance Antiphon}

Chlubimy się krzyżem naszego Pana Jezusa Chrystusa;

w nim jest nasze zbawienie, życie i zmartwychwstanie, przez niego jesteśmy zbawieni i oswobodzeni (Cf. Galatians 6:14). ${ }^{16}$

\subsection{Historical-Critical Analysis}

The proper understanding of Galatians 6:14 requires looking at the context described in Galatians 6:12-13, where St. Paul presents the false intentions of the troublemakers who have come to Galatia. Those people want first to impress people (verse 12). They do not care about fulfilling the law, but about their personal fame. They want to boast of their statistics which show how many non-believers were brought back to their way and how much effort they had put into that. They act only for the sake of their own glory and recognition. Such an attitude of the pseudo-zealots is criticized by Christ in the Gospel of St. Matthew (Matthew 23:15) ${ }^{17}$.

Apart from that, those false teachers are driven by their fear of suffering caused by the opponents of Christ, especially the Jews. In this way, they reveal their ignorance of the value of Christ's death on the Cross. To Paul, Christ's Cross is the only boast because through it "the world" was crucified for the Apostle, and he-for "the world" (verse 14). That confession exhibits the Apostle's strength of conviction and his fidelity. The Cross of our Savior is the place of Christ's death for our sins (Romans 6:10), but Paul was crucified together with Christ in order to die to the law (Galatians 2:19). On the Cross, all the people who were united with Christ died, and in this way, the flesh died together with all its passions and desires (Galatians 5:24). Finally, our old self died on the Cross (Romans 6:6). Thanks to the Cross, sin, selfishness, and everything that is described as "the world" ceased to exist ${ }^{18}$.

The crucifixion of the world for Paul and of Paul for the world means that in the Apostle's eyes, the world has lost all power and value. In a similar vein, Paul has no significance in the eyes of the world. Through the Cross, Christ became the Lord (Philippians 2:8-11) and he triumphed over the elements of the old world (Colossians 2:15) ${ }^{19}$.

In the concluding verse (verse 15), St. Paul claims that nothing is important before the Cross: neither circumcision nor lack of it because everyone, with no exceptions, needs salvation coming from Christ's Cross ${ }^{20}$.

It bears emphasizing that Paul wrote the whole conclusion of the Letter to Galatians (6:11-18) himself (a practice confirming authenticity) and in capital letters, which was

13 Holy See (2013), Mszał rzymski dla diecezji polskich, Poznań-hereafter abbreviated as MR.

14 Bible source can be listed as Primary soucer without using Author Names when cited. Biblia Tysiaclecia, Poznań 2015.

15 Cf. Popowski Remigiusz (1994) Grecko-polski Nowy Testament, trans. R. Popowski, M. Wojciechowski, Warszawa 1994.

16 We boast of the Cross of our Lord, Jesus Christ; in it there is our salvation, life and resurrection, through it we are saved and set free (my own literal translation). In the present paper, I use my own literal translations of the antiphons and quotations from the Bible rather than their English versions available from the English translation of the Roman Missal or the Bible. In this way, I aim to help the readers identify the similarities and differences present in the Polish versions of the texts, in line with the assumption of this study.

17 Cf. E. Szymanek (1978), List do Galatów. Wstęp-przektad z oryginatu-komentarz, ed. E. Szymanek, Poznań-Warszawa, p. 117.

18 Cf. Elsa Tamez (1978), List do Galatów, in: Międzynarodowy Komentarz do Pisma Świętego, ed. W. Chrostowski, Warszawa, p. 117.

19 Cf. Lech Stachowiak (1999), Komentarz praktyczny do Nowego Testamentu, vol. 2, ed. L. Stachowiak, Poznań-Kraków, p. 245.

20 Cf. ibid. 
something new. Perhaps in this way he wanted to draw the readers' attention to those particular words that call to be proud of Christ's Cross ${ }^{21}$.

\subsection{Syntactic-Semantic Analysis}

ANTIPHON: a Chlubimy się krzyżem naszego Pana Jezusa Chrystusa; w nim jest nasze zbawienie, życie i zmartwychwstanie, $\quad{ }^{b}$ przez niego jesteśmy ${ }^{{ }^{c} \text { zbawieni } \mathrm{i}}$ oswobodzeni (Cf. Galatians 6:14). ${ }^{22}$

THE MILLENIUM BIBLE: Co do mnie, nie daj Boże $\mathrm{e}^{\mathrm{A}}$, abym się miał chlubić z czego innego, jak tylko z krzyża Pana naszego Jezusa Chrystusa ${ }^{\mathrm{B}},{ }^{\mathrm{b}}$ dzięki ${ }^{\mathrm{C}}$ któremu ${ }^{c}$ świat stał się ${ }^{\mathrm{D}}$ ukrzyżowany dla mnie, a ja dla świata. ${ }^{23}$

THE LITERAL TRANSLATION: Co do mnie zaś, w żadnym razie ${ }^{A}$ nie będę się

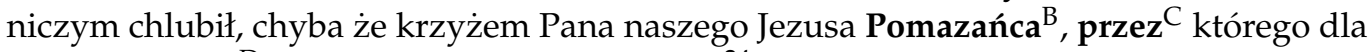
mnie świat jest ${ }^{\mathrm{D}}$ ukrzyżowany-a ja dla świata. ${ }^{24}$

The antiphon from the Roman Missal (ANT) contains the plural form of the verb, "chlubimy się" (we boast), unlike the Millennium Bible (MB) and the literal translation (LT), where Paul is writing about himself in the singular number. ANT and LT use the expression "przez niego" (through which) with reference to the Cross, while MB uses the expression "dzięki któremu" (thanks to which). ANT contains a sentence that is absent from MB and LT: "w nim jest nasze zbawienie, życie I zmartwychwstanie" (in it there is our salvation, life and resurrection). It seems to be an ecclesiastical interpretation of the fruit born by "crucifixion and boasting of the Cross". Additionally, the expression "zbawieni i oswobodzeni" (saved and set free) from ANT seems to be the fruit of "being crucified for the world".

Another issue worth our attention is the comparison of MB and LT, especially the expression "nie daj Boże" (God, do not allow) from MB, which replaces the literal version "w żadnym razie" (in no case). The word "Chrystus" (Christ) from MB corresponds to "the Anointed One" from LT. MB says "świat stał się" (the world has become), while LT reads "swiat jest" (the world is).

\subsection{Pragmatic Analysis}

The fragment of the letter is written in the context of Christ's crucifixion. Christ's physical suffering ended, but new sufferings (crosses) appeared-persecutions of the Church members.

In such a context, the call to boast only of the Cross of Christ, which is expressed in a very categorical manner, becomes a call to change one's way of thinking and setting one's values. God and his mission of delivering man should be the most important, while everything else should be subordinated to that cause. St. Paul declares the priority of God in his own life and encourages the reader to do the same.

The translation from the MB, which reads "nie daj Boże" (God, do not allow me), calls for a humble prayer: God, do not allow me to make anything more important than you. That thought encourages us to become humble and to realize that succumbing to temptations may reverse our attitude.

\section{The Antiphons for the Washing of Feet}

In this section, we analyze all the antiphons used during the rite of the Washing of Feet from the Mass of the Lord's Supper.

21 Cf. E. Tamez (2001), List do Galatów, in: Międzynarodowy komentarz do Pisma Świętego, ed. W. Chrostowski, Warszawa, p. 1520.

22 For the literal translation see footnote 9.

23 When it comes to me, God, do not allow me to boast of anything else than the Cross of our Lord, Jesus Christ, thanks to which the world has become crucified for me, and I-for the world (my own literal translation).

24 When it comes to me, in no case shall I boast of anything, except the Cross of our Lord, Jesus the Anointed One, through which the world is crucified for me, and I-for the world (my own literal translation). 


\section{The First Antiphon}

Gdy Pan wstał od wieczerzy, nalał wody do miednicy i zaczął umywać uczniom nogi; taki przykład im zostawił (Cf. John 13:4, 5, 15). ${ }^{25}$

\subsection{Historical-Critical Analysis}

The antiphon comes from the Gospel of St. John (13:4), but it omits the first part of the sentence which provides us with the important context of "standing up after the supper". The beginning of the whole sentence reads: "Jezus wiedzac, że Ojciec wszystko złożył w Jego rece i że wyszedł od Boga i do Boga odchodzi, powstaje od wieczerzy ... " (John 13:3). ${ }^{26}$ Jesus is aware of his participation in God's omnipotence and his mandate from the Father to grant eternal life to those who believe in the Son (verse 3). Throughout the whole time of his public ministry, Jesus was aware of his unity with the Father, and now, right before his return to the Father, the Evangelist emphasizes the fact that it will be a return in glory (Cf. 16:28). The awareness of his glorious return to the Father is strictly connected with the gesture of humility and love, seen in the washing of the disciples' feet. The clear and direct affirmation of Jesus' divine dignity stands in opposition to the act of the washing of feet, which was usually performed by slaves. However, that gesture means following humble love which is ready for unconditioned service. Jesus' divine majesty is best manifested in such a kind of love (Cf. Philippians 2:6-8). Jesus' reign is realized above all in service ${ }^{27}$.

Before all kinds of ancillary works, people folded or girded their clothes. That action had its practical dimension: the long robes worn in Palestine could make strenuous work difficult. Thus, Jesus' gesture of putting away his robes highlights his humility and readiness to strenuous work or serving the Apostles ${ }^{28}$.

The exceptional character of Jesus' attitude emphasizes the fact that although traditionally it was the host who gave his guests water to wash their feet as a proof of his hospitality (Genesis 18:4), the act of untying sandals and personal washing was not performed even by servants. ${ }^{29}$

The atmosphere of humility and loving commitment takes its full dimensions in light of Judas' maturing betrayal and Jesus' incoming death. The washing of feet leads us to the sacramental dimension ${ }^{30}$, and especially the purification through Jesus' death ${ }^{31}$.

The last part of the antiphon refers to verse 15: "Dałem wam przykład, abyście czynili tak, jak Ja wam uczyniłem"32. Again, the full understanding of the sense of that sentence is hidden in the preceding sentence: "Jeżeli więc Ja, będąc Panem i Nauczycielem, umyłem wam nogi, także wy powinniście umywać nogi jeden drugiemu" ${ }^{\prime 33}$ (verse 14) ${ }^{34}$.

If Jesus, as the Lord who has divine dignity, served his disciples, then each of his disciples ought to serve his neighbors in the spirit of humility and love. Those two inseparable Christian attitudes take their value from following Christ, who sacrificed his life and relinquished all things for the sake of our salvation in the same spirit. Thus, the

25 When the Lord stood up after the supper, he poured water into a basin and started to wash his disciples' legs; such an example he left them (my own literal translation).

26 Knowing that the Father has put everything in his hands and that he came from God and is going back to God, Jesus stands up after the super ... (my own literal translation).

27 Cf. Lech Stachowiak (1975), Ewangelia wedtug św. Jana. Wstęp-przekład z oryginału-komentarz, ed. L. Stachowiak, Poznań-Warszawa, pp. 300-1.

28 Lech Stachowiak (1998), Komentarz praktyczny do Nowego Testamentu, vol. 1, ed. L. Stachowiak, Poznań-Kraków, p. 523.

29 Craig S. Keener (2000), Komentarz historyczno-kulturowy do Nowego Testamentu, Warszawa, p. 215.

30 The sacramental dimension means that the material dimension (e.g., water) is used for communication referring to the invisible reality. In the same way we can characterize the three sacramental dimensions: Jesus Christ in his mystery of incarnation, the Church as a whole, and the Christian sacramental rites. In all those three moments the material dimension constitutes a carrier of the content which exceeds the visible aspect perceived by senses. That means that we can talk about changing the ordinary material element and about its real transsignificatio, which can be observed in the case of the Christian sacramental rites, where for instance water used in baptism communicates grace. Cf. A. Dańczak (2019), Locutio mundi-znaczenie i zakres określenia "sakramentalność świata", Studia Gdańskie, vol. XXV, p. 15.

31 Cf. Lech Stachowiak (1975), Ewangelia według św. Jana. Wstęp-przekład z oryginału-komentarz, p. 301.

32 I have given you an example so that you can do what I have done to you (my own literal translation).

33 If I as the Lord and Teacher, have washed your legs, then also you should wash each other's legs (my own translation).

34 Cf. ibid. 
point is not to follow materially Jesus' gesture of the washing of feet, but to carve out an attitude to be ready to serve and humble oneself before people in such a way. That is how the word "example" should be understood-as a call to put love into practice in everyday life. The gesture of the washing of feet is not only an example to be imitated, but it also constitutes a symbol of Christ's greatest service-his death on the Cross, which was necessary for our salvation ${ }^{35}$.

\subsection{Syntactic-Semantic Analysis}

ANTIPHON: Gdy Pan wstał od wieczerzy, nalał wody do miednicy i zaczął umywać

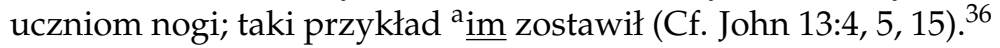

THE MILLENNIUM BIBLE: Wstał ${ }^{\mathrm{A}}$ od wieczerzy i złożył szaty. A wziąwszy prześcieradło $^{\mathrm{B}}$ nim się przepasał. Potem nalał ${ }^{\mathrm{C}}$ wody do miednicy. I zaczą umywać uczniom nogi i ocierać prześcieradłem, którym był przepasany. Dałem ${ }^{\mathrm{a}} \underline{\mathrm{w} a m}$ bowiem przykład, abyście i wy tak czynili, jak Ja wam uczyniłem.$^{37}$

THE LITERAL TRANSLATION: Wstaje ${ }^{A}$ od wieczerzy, złożył szaty, wziął płócienny ręcznik $^{B}$ i przepasał się (nim). Potem leje $\mathrm{C}^{C}$ do miednicy wody i zaczął myć nogi uczniów, i wycierać ręcznikiem, którym jest przepasany. Dałem wam bowiem przykład, abyście i wy czynili tak, jak Ja wam uczyniłem. ${ }^{38}$

ANT is clearly shorter than MB: a few expressions are missing-“złożył szaty” (he folded his robes), "ocierać prześcieradłem, którym był przepasany" (to mop with the sheet he was girded with), and "abyście i wy tak czynili, jak Ja wam uczyniłem" (so that you can do as I have done to you). ANT is talking about the example given to the disciples-"im" (them) (3rd person) while MB and LT have the word "wam"39 (you) (2nd person). LT uses the present tense in "wstaje" 40 (he stands up) and "leje" $\mathrm{e}^{41}$ (he pours) while in MB there is the past tense: "wstał" (he stood up) and "nalał" (he poured).

\subsection{Pragmatic Analysis}

The fragment from St. John's Gospel depicts Jesus as someone humble, who goes beyond customs and traditions in order to show his exceptional love for man. Although the antiphon lacks the expression "złożył szaty" (he folded his robes), the context encourages us to see in this scene Jesus who girds himself with a sheet and prepares for some hard menial work ${ }^{42}$. The present tense used in the Greek text suggests that Jesus' self-abatement continues and takes place today, in our reality. Jesus wants to serve us today.

\section{The Second Antiphon}

Jezus podszedł do Szymona Piotra, a on rzekł do Niego: Panie, Ty chcesz mi umyć nogi? Jezus mu odpowiedział: Jeśli Cię nie umyję, nie będziesz miał udziału ze Mną. Tego, co Ja czynię, ty teraz nie rozumiesz, ale później będziesz to wiedział. Panie, Ty chcesz mi umyć nogi (Cf. John 13:6, 7, 8). ${ }^{43}$

35 Cf. Lech Stachowiak (1975), Ewangelia według św. Jana. Wstęp-przekład z oryginału-komentarz, p. 301.

36 For the literal translation, see footnote 18.

37 He stood up after the supper and folded his robes. And he took a sheet and girded himself with it. Then he poured water to the basin. And he started washing the disciples' legs and mopping them with the sheet he was girded with. For I have given you an example so that you can do what I have done to you (my own literal translation).

38 He stands up after the supper, folded his robes, took a linen towel and girded himself (with it). Then he pours water to the basin and started washing the disciples' legs and mopping them with the towel he was girded with. For I have given you an example so that you can do what I have done to you (my own literal translation).

39 Greek hymin (pp 2 Dat Pl)-personal pronoun, second person, dative case, plural number.

40 Greek egeiretai (vi Pres Pas 3 Sg)-verb, indicative mood, present tense, passive voice, third person, singular number.

41 Greek ballei (vi Pres Act $3 \mathrm{Sg}$ )-verb, indicative mood, present tense, active voice, third person, singular number.

42 Cf. Craig S. Keener (2000), Komentarz historyczno-kulturowy do Nowego Testamentu, Warszawa, p. 215.

43 Jesus approached Simon Peter, who said to him: Lord, do you want to wash my legs? Jesus answered him: If I do not wash you, you will not have part with me. What I am doing you do not understand now, but you will know it later. Lord, you want to wash my legs (my own literal translation). 


\subsection{Historical-Critical Analysis}

The fragment from the Gospel of St. John (John 13:6-8) points to Peter's reaction to Christ's gesture of the washing of feet. Folding the robes by Jesus and girding with the sheet are gestures of a servant preparing for work. Those gestures highlight Jesus' humility. Probably Peter is the first disciple that has his feet washed by Jesus, and that is why his protest seems more understandable. It is a protest of a person who has decided to follow Christ but who cannot understand the intrinsic connection between that act, typical of a slave, and the person and mission of Jesus. His idea of Moses from the Old Testament excludes that kind of humiliation despite the fact that the Teacher has already rebuked him in similar circumstances (Cf. Mark 8:32) ${ }^{44}$.

However, Jesus points to Peter's later understanding of his mission. The word "później" (later) can be interpreted in two ways: as an allusion to the complete humiliation on the Cross, which is about to happen, and which seems to be the most probable, or in the further sense, as an allusion to the enlightenment granted by the Holy Spirit after the resurrection of glorified Christ. Unfortunately, Peter refuses to accept that explanation similarly to what happened in Caesarea Philippi (Matthew 16:22). He is driven by his deep affection toward Jesus, which prevents him from accepting such a deep humiliation of his Master. He fails to notice the intrinsic relationship between humiliation and salvation brought by the crucified Savior. Only the next explanation provided by Jesus convinces Peter, who then opens to the gesture of the washing of feet (verse 9) ${ }^{45}$.

The gesture of the washing of feet is also connected to the Anointing at Bethany, which took place in the paschal week during a supper, raising the observers' resistance and breaking all known conventions ${ }^{46}$.

\subsection{Syntactic-Semantic Analysis}

ANTIPHON: Jezus podszedł do Szymona Piotra, a on rzekł do Niego: Panie, Ty chcesz mi umyć nogi? Jezus mu odpowiedział: Jeśli Cię nie umyję, nie będziesz miał udziału ze Mną. Tego, co Ja czynię, ty teraz nie rozumiesz, ale później będziesz to wiedział. ${ }^{a}$ Panie, Ty chcesz mi umyć nogi (Cf. John 13:6, 7, 8). ${ }^{47}$

THE MILLENNIUM BIBLE: Podszedł więc do Szymona Piotra, a on rzekł ${ }^{\mathrm{A}}$ do Niego: Panie, Ty chcesz mi umyć nogi? Jezus mu odpowiedział: Tego, co Ja czynię, ty teraz nie rozumiesz, ale później będziesz to wiedział ${ }^{\mathrm{B}}$. Rzekł do Niego Piotr: ${ }^{\mathrm{a}} \mathrm{Nie}$, nigdy $^{\mathrm{C}}$ mi nie będziesz nóg umywał. Odpowiedział mu Jezus: Jeśli cię nie umyję, nie będziesz miał ${ }^{\mathrm{D}}$ udziału ze Mna. ${ }^{48}$

THE LITERAL TRANSLATION: Podchodzi też do Szymona Piotra, a ten Mu rzecze $^{\mathrm{A}}$ : Panie, Ty mi chcesz myć nogi? Jezus mu odpowiedział: Co Ja czynię - ty teraz nie rozumiesz, ale potem pojmiesz ${ }^{\mathrm{B}}$. Piotr na to: Nie będziesz mył moich nóg. Na wiek! ${ }^{C}$ A Jezus: Jeśli cię nie umyję, nie masz ${ }^{\mathrm{D}}$ ze Mną działu. ${ }^{49}$

ANT contains a mitigated version of Peter's protest against the sign of the washing of feet. Instead of the radical objection in MB: "Nie, nigdy mi nie będziesz nóg umywał" (No, you will never wash my legs) or the expression: “Na wiek!" (Never ever!) in LT, the Roman Missal uses only a declarative sentence (there is even no question mark in it): "Panie, Ty chcesz mi umyć nogi" (Lord, you want to wash my legs). That sentence from ANT seems

Cf. Lech Stachowiak (1975), Ewangelia według św. Jana. Wstęp-przekład z oryginału-komentarz, pp. 302-3.

Cf. Lech Stachowiak (1999), Komentarz praktyczny do Nowego Testamentu, vol. 1, p. 524.

6 Cf. Teresa Okure (2001), Ewangelia Według św. Jana: Międzynarodowy Komentarz do Pisma Świętego, p. 1348.

7 For the literal translation see footnote 35.

48 Thus, he approached Simon Peter, who said to him: Lord, do you want to wash my legs? Jesus answered him: What I am doing you do not understand now, but you will know it later. Peter told him: No, you will never wash my legs. Jesus answered him: If I do not wash you, you will not have part with me (my own literal translation).

49 He also approaches Simon Peter, who says to him: Lord, do you want to wash my legs? Jesus answered him: What I am doing you do not understand now, but you will understand later. Peter replied: You will not wash my legs. Never ever! And Jesus: If I do not wash you, you do not have part with me (my own literal translation). 
to express a reflection rather than a radical objection. When describing Peter's words, MB uses the verb "rzekł" (said) in the past tense while LT contains the verb "rzecze"50 (says) in the present tense. Similarly, in MB we read "nie będziesz miał udziału" (you will not have part) while in LT there is the present tense: "nie masz" 51 (you do not have).

\subsection{Pragmatic Analysis}

The literal sense of the antiphon presents Peter as someone calm, thoughtful, and submerged in the mystery of Jesus' surprising gesture. However, the exegetic analysis allows us to see all our objections to God's will in Peter's resistance. Every "no" said to God results in losing grace (part with Jesus) prepared for us by Jesus. The present tense in "nie masz udziału" (you have no part) suggests that the consequences of man's objection to God are immediate; sin breaks our connection with Christ "now", and not in some unclear distant future.

\section{The Third Antiphon}

Jeżeli Ja, wasz Pan i Nauczyciel, umyłem wam nogi, to i wyście powinni sobie nawzajem umywać nogi (Cf. John 13:14). ${ }^{52}$

\subsection{Historical-Critical Analysis}

The verse from John 13:14 is crucial to explain Jesus' behavior toward his traitor. Jesus has known about Judas' betrayal since the beginning of his public ministry (John 6:70), but the words he uttered then have remained unnoticed. It is necessary to read them as a discreet warning, full of tact and subtlety, addressed to the traitor himself. Unfortunately, they did not impress him. This kind of Jesus' attitude is explained in verse 14-Christ, Lord and Teacher, wants to serve, wash, and save every man, even the one that betrays him ${ }^{53}$.

If Jesus performs an ancillary work despite being perceived by everyone as "Rabbi", and by his disciples as "Lord", in this way he obliges everyone to serve each other. The proper dimension of that love will be seen on the Cross and his complete self-abatement, which involves suffering and death ${ }^{54}$.

\subsection{Syntactic-Semantic Analysis}

ANTIPHON: Jeżeli Ja, wasz Pan i Nauczyciel, umyłem wam nogi, to i wyście powinni sobie nawzajem umywać nogi (Cf. John 13:14). ${ }^{55}$

THE MILLENNIUM BIBLE: Jeżeli więc Ja, Pan i Nauczyciel, umyłem wam nogi ${ }^{\mathrm{A}}$, to i wyście powinni sobie nawzajem umywać nogi ${ }^{\mathrm{B}}{ }^{56}$

THE LITERAL TRANSLATION: Jeśli więc Ja umyłem Wam stopy ${ }^{\mathrm{A}}$, Pan i Nauczyciel, i wy powinniście myć sobie stopy ${ }^{\mathrm{B}}{ }^{57}$

The antiphon from the Missal contains an extra word "wasz" (your) (Lord) while neither MB or LT use that word ${ }^{58}$. ANT and MB mention "nogi" (legs) twice while LT uses the word "stopy" 59 (feet).

Greek legei (vi Pres Act $3 \mathrm{Sg}$ )-verb, indicative mood, present tense, active voice, third person, singular number.

Greek echeis (vi Pres Act $2 \mathrm{Sg}$ )-verb, indicative mood, present tense, active voice, second person, singular number.

5 If I, your Lord and Teacher, have washed your legs, then also you should wash each other's legs (my own literal translation).

Lech Stachowiak (1975), Ewangelia według św. Jana. Wstęp-przekład z oryginału-komentarz, p. 304.

4 Cf. Lech Stachowiak (1999), Komentarz praktyczny do Nowego Testamentu, vol. 1, p. 525.

55 For the literal translation see footnote 44.

56 Thus, if I, Lord and Teacher, have washed your legs, then you also should wash each other's legs (my own literal translation).

57 Thus, if I have washed your feet, Lord and Teacher, also you should wash each other's feet (my own literal translation).

58 The original Greek text contains only the article (ho kyrios and ho didaskalos) ho (t__Nom Sg m)-article, nominative case, singular number, masculine gender.

59 Greek podas (n_ Acc Pl m)-noun, accusative case, plural number, masculine gender. 


\subsection{Pragmatic Analysis}

Adding the word "wasz" (your) in the Roman Missal may restrict Jesus' declaration concerning his mission. He is the Lord and Teacher of all, even of those who refuse to listen to him and follow him. His reign is not limited to a specific group, and his wisdom is timeless. In this place it is necessary to notice that in 2016 Pope Francis changed the rubrics in the Roman Missal (Missale Romanum, p. 300, no. 11), from "The men who have been chosen are led by the ministers ... " to "Those who are chosen from amongst the people of God are led by the ministers ... " $" 60$. Thus, the Pope emphasizes the fact the sign of the washing of feet is directed at every human being; everyone (not only men) is invited to approach Christ in order become purified.

LT seems to be more precise in the description of the part of the body that was washedthe feet. That fact is confirmed by the historical and cultural commentary ${ }^{61}$. Thanks to the grace of the sacraments we can feel completely clean, and what needs to be washed is what symbolically touches the world (the earth), that is the symbolic feet in our life.

Jan van der Watt argues that the connection between love and "foot" expresses Jesus' idea that disciples should become like slaves, and humiliating service is not sufficient to achieve perfection ${ }^{62}$.

\section{The Fourth Antiphon}

Po tym wszyscy poznają, że jesteście moimi uczniami, jeśli będziecie się wzajemnie miłowali (Cf. John 13:35). ${ }^{63}$

\subsection{Historical-Critical Analysis}

The fragment of the Gospel of St. John (John 13:35) points to the duty of being a witness of Christ through love. That love should be special because it should follow Jesus' example (verse 34)-“jak Ja was umiłowałem" (like I have loved you). This is the nature of Christian love, which was beautifully expressed with humility in Jesus' gesture of the washing of the disciples' feet. A Christian is called not only to the "ordinary" imitation of Jesus' gestures and words, but to become involved in love, which ought to be pursued by every disciple. What is more, mutual love constitutes a characteristic of Christ's disciples and it distinguishes them from the rest of the world ${ }^{64}$.

That commandment is a proof of the identity of a true disciple. It accompanies the new covenant of love, just like the Torah accompanied the covenant from Mount Sion. It is a new commandment because the benchmark of the required love is Jesus' love for us and not the love we have for each other ${ }^{65}$.

The novelty of the commandment of love, which was known in the Old Testament (Leviticus 19:18), lies also in its rank: it is promoted from a secondary postulate, absent from the Decalogue, to the chief commandment, which exceeds borders and nations, but is founded on the unity with Jesus. That love is a supernatural gift, which results from being united with Jesus, the Vine, but which finally is connected to the Son of God's sacrifice on the Cross (Cf. 1 John 3:16-18) ${ }^{66}$.

\subsection{Syntactic-Semantic Analysis}

ANTIPHON: Po tym wszyscy poznaja, że jesteście moimi uczniami, jeśli będziecie się wzajemnie miłowali (Cf. John 13:35). ${ }^{67}$

\footnotetext{
60 Congregatio de Cultu Divino et Disciplina Sacramentorum (2016), Dekret “In missa in cena Domini”, in: http:/ /www.vatican.va/roman_curia/ congregations/ccdds/documents/rc_con_ccdds_doc_20160106_decreto-lavanda-piedi_en.html (accessed on 8 October 2020).

61 Cf. Craig S. Keener (2000), Komentarz historyczno-kulturowy do Nowego Testamentu, Warszawa, p. 215.

62 Jan van der Watt (2017), The Meaning of Jesus Washing the Feet of His Disciples (John 13), Neotestamentica, Vol. 51, No. 1 (2017), p. 27.

3 By this everyone will know that you are my disciples, if you love each other (my own literal translation).

64 Cf. Lech Stachowiak (1975), Ewangelia według św. Jana. Wstęp-przekład z oryginału-komentarz, p. 309.

65 Cf. Teresa Okure (2001), Ewangelia według św. Jana, p. 1349.

66 Cf. Lech Stachowiak (1975), Ewangelia wedtug św. Jana. Wstęp-przekład z oryginału-komentarz, p. 309.

67 For the literal translation see footnote 53
} 
THE MILLENNIUM BIBLE: Po tym wszyscy poznaja, żeście uczniami moimi ${ }^{\mathrm{A}}$, jeśli będziecie ${ }^{\mathrm{B}}$ się wzajemnie miłowali. ${ }^{68}$

THE LITERAL TRANSLATION: Po tym wszyscy poznają, że jesteście moi uczniowie $^{\mathrm{A}}$, jeśli miłość mielibyście ${ }^{\mathrm{B}}$ między sobą nawzajem. ${ }^{69}$

The antiphon is a literal quotation from MB. Interestingly, the expression "moimi uczniami" (my disciples) in MB and ANT is in the instrumental case, while in LT, it is in the nominative case: "moi uczniowie" (my disciples) ${ }^{70}$. Additionally, the verb form "mielibyście ${ }^{71}$ miłość" $^{\text {ch }}$ (you would have love) in LT is particular. In all the three versions of the text there is the word "wszyscy"72 (everyone), which makes Jesus' words more radical.

\subsection{Pragmatic Analysis}

Perhaps the conditional mood of the verb "mieć" (to have) love shows that Jesus is aware of the fact that our love is not perfect yet and it fails to be the identification mark of Christians in the world. Additionally, the broader context of the Gospel, especially of the scene of sending the Apostles to the mission, shows that the expression "mieć miłość między soba" (have love for each other) is not an invitation to stay in that small group of believers, but to open to others-then, "między soba" (for each other) would mean: everywhere we are. Jesus' radical word "wszyscy" (everyone) points to the fact that love is a reliable tool for the evangelization of the world and the most important identification mark.

\section{The Fifth Antiphon}

Daje wam przykazanie nowe, abyście się wzajemnie miłowali, tak jak Ja was umiłowałem (Cf. J 13:34). ${ }^{73}$

\subsection{Historical-Critical Analysis}

In the Gospel of St. John, the commandment of love is presented by Jesus in a very affectionate way-he speaks to his disciples as if they were children (John 13:33). The commandment of love seems to answer the expected parting with Jesus. By their mutual love the disciples may stay with Jesus despite his physical absence. Thus, the upcoming parting is mitigated by the Jesus' promises to stay with his disciples in the mystery of mutual love.

Loving each other is the proper attitude of each member of the Christian community, awaiting Christ's second coming. In this light, the commandment ought to be understood as Jesus' guideline, which leads us to the fullness of the life that he is going to prepare for us. Paul calls it "the law of Christ". The content of the commandment is mutual love among Christians, which imitates Jesus' love for them. The Old Testament advised loving neighbors (Cf. Leviticus 19:18). Jesus extends that love to everyone with no exceptions, even one's enemies (Cf. Luke 10:29, 36) ${ }^{74}$.

\subsection{Syntactic-Semantic Analysis}

ANTIPHON: Daję wam przykazanie nowe, abyście się wzajemnie miłowali, tak jak Ja was umiłowałem (Cf. John 13:34). ${ }^{75}$

By this everyone will know that you are my disciples, if you love each other (my own literal translation).

69 By this everyone will know that you are my disciples, if you would have love for each other (my own literal translation).

70 Greek emoi mathētai (n_Nom Pl m)-noun, nominative case, plural number, masculine gender.

71 Greek echête (vs. Pres Act 2 Pl)-verb, conditional mood, present tense, active voice, second person, plural number.

72 Greek pantes (a_Nom Pl m)-adjective, nominative case, plural number, masculine gender.

73 I give you a new commandment to love each other like I have loved you (my own literal translation).

74 Cf. Ewangelia wedtug św. Jana. Wstęp-przekład z oryginału-komentarz, p. 308.

75 For the literal translation see footnote 63. 
THE MILLENNIUM BIBLE: Przykazanie nowe daję wam, abyście się wzajemnie miłowali $^{\mathrm{A}}$ tak, jak Ja was umiłowałem; żebyście i wy tak się miłowali ${ }^{\mathrm{B}}$ wzajemnie.$^{76}$

THE LITERAL TRANSLATION: Przykazanie nowe daje wam, aby miłowalibyście $^{\mathrm{A}}$ siebie tak, jak umiłowałem was, aby i wy miłowalibyście ${ }^{\mathrm{B}}$ jedni drugich. ${ }^{77}$

The antiphon from the Roman Missal does not contain the repetition present in MB: "żebyście i wy tak sie miłowali" (so that you love each other). In all the versions of the text the verb "dawać"78 (to give) (the commandment) is used in the present tense, in the $1^{\text {st }}$ person singular. In LT, the verb "miłować" (to love) is used in the conditional mood: "miłowalibyście"79 (you would love). Apart from its form, also the verb describing love used is different-it is agape, which means charity: perfect love that is full of devotion and which comes from God.

\subsection{Pragmatic Analysis}

The repetition of the expression "żebyście i wy tak sie miłowali" (so that you love each other) found in MB and LT shows the rank of this commandment. Jesus wants to repeat, that means to emphasize, the fact that the commandment of love is the most important one in the whole Christianity. Choosing the verb agape for love shows that God makes great demands-that verb means perfect love, whose roots are in God. The model of conduct that is suggested by the text means love defined by Jesus' sacrifice on the Cross-suffering. For the reader, the model of conduct is Jesus' readiness for self-abandonment and sacrifice for the other person ("like I have loved you").

\section{The Sixth Antiphon}

Niechaj trwają w was wiara, nadzieja i miłość. Z nich największa jest miłość. Teraz trwają wiara, nadzieja i miłość. Z nich największa jest miłość (Cf. 1 Corinthians 13:13). ${ }^{80}$

\subsection{Historical-Critical Analysis}

The verse from 1 Corinthians 13:13 surmounts the whole Hymn of Love (13:1-13), which is considered to be the most beautiful hymn ever created to honor love. Even people who have nothing in common with Christianity compare that hymn with the greatest poems in the classical Greek literature. With no doubt, when Paul wrote about love, he was thinking about Jesus dying for us. Thus, it is not surprising that every sentence here will still make sense when we replace the word "love" with the name "Jesus" 81.

The verse from 1 Corinthians 13:13, which is used in the antiphon, belongs to the third part of the hymn, called "The Absolute Primacy of Love" (Part 1: "The Highness and Necessity of Love"-verses 1-3; Part 2: "Attributes of Love"-verses 4-7; Part 3: "The Absolute Primacy of Love"-verses 8-13) ${ }^{82}$.

Paul shows that love is a virtue that surpasses all the other gifts because it is eternal while the gifts are temporal ${ }^{83}$.

Love is greater even than faith and hope, those two virtues whose object is also God, and which are strongly recommended by the Apostle to his listeners in numerous places. There will be a time when people stop living by hope because they achieve what they have

\footnotetext{
76 I give you a new commandment to love each other like I have loved you, so that you love each other in the same way (my own literal translation).

77 I give you a new commandment so that you would love each other like I have loved you, so that you would love each other (my own literal translation).

78 Greek didōmi (vi Pres Act $1 \mathrm{Sg}$ )-verb, indicative mood, present tense, active voice, first person, singular number.

79 Greek agapate (vs Pres Act $2 \mathrm{Pl}$ )-verb, conditional mood, present tense, active voice, second person, plural number.

80 Let faith, hope, and love abide in you. The greatest of these is love. Now, faith, hope, and love abide. The greatest of these is love (my own literal translation).

81 Cf. Lech Stachowiak (1999), Komentarz praktyczny do Nowego Testamentu, vol. 1, p. 152.

82 Cf. ibid.

83 Cf. Craig S. Keener (2000), Komentarz historyczno-kulturowy do Nowego Testamentu, Warszawa, p. 366.
} 
expected all their lives. Additionally, faith will become unnecessary because people will see God directly. A testimony and mediator will become unnecessary. Only love will last ${ }^{84}$.

\subsection{Syntactic-Semantic Analysis}

ANTIPHON: ${ }^{a}$ Niechaj trwaja $\mathrm{w}$ was wiara, nadzieja i miłość. $Z$ nich największa jest miłość. Teraz trwaja wiara, nadzieja i miłość. $Z$ nich największa jest miłość (Cf. 1 Corinthians 13:13). ${ }^{85}$

THE MILLENNIUM BIBLE: ${ }^{\mathrm{a}}$ Tak $^{\mathrm{A}}$ więc trwają wiara, nadzieja, miłość- te trzy ; z nich zaś największa jest miłość. ${ }^{86}$

THE LITERAL TRANSLATION: Teraz ${ }^{\mathrm{A}}$ zatem pozostają wiara, nadzieja, miłośćte trzy ; a z nich największa jest miłość. ${ }^{87}$

ANT contains a repetition of virtually the whole verse 13:13 (without the expression " $w$ was" (in you)). Adding the expression "w was" (in you) in the first part of the antiphon is not based on the original text. LT does not provide information about the "place" where the virtues abide. ANT begins with the word "niechaj" (let), MB with "tak" (thus), and LT uses the word "teraz" 88 (now).

\subsection{Pragmatic Analysis}

The repetition of the whole sentence in the antiphon may be a tool used by some editors to strengthen the message of that text, which constitutes the most important commandment of love. Changing the first word of ANT into "niechaj" (let) contorts the sense of the word "tak" (thus) that can be found in the source or the word "teraz" (now) in LT, which emphasizes the validity of the commandment in our everyday life. That commandment is not something that was given the other day in history, but it is something constantly repeated by Jesus, who says to us "now". Adding the words "w was" (in you) in ANT also restricts Jesus' message. Love, faith, and hope are theological virtues. Their source, motive, and direct object is God himself. They are engrafted together with sanctifying grace, enabling people to commune with the Holy Trinity, and shape and animate moral virtues $^{89}$. Thus, those virtues refer directly to God as their Source, as well as the Goal that they aim at. For that reason they are universal and they do not abide only "w was" (in you), meaning Christ's disciples.

\section{The Offertory Antiphon}

Ref.: Gdzie miłość prawdziwa i dobroć, tam znajdziesz Boga żywego. ${ }^{90}$

Zgromadziła nas tu razem miłość Chrystusa, *

weselmy się w Nim i radujmy.

Z pokora szczera kochajmy Boga *

i czystym sercem miłujmy się nawzajem. ${ }^{91}$

Skoro się wszyscy tu gromadzimy, *

strzeżmy się tego, co nas rozdziela.

Niech ustana wszystkie gniewy i spory, *

84 Cf. Lech Stachowiak (1999), Komentarz praktyczny do Nowego Testamentu, vol. 1, p. 152.

85 For the literal translation see footnote 70.

86 Thus, faith, hope, and love abide-those three; whereas the greatest from these is love (my own literal translation).

87 Now, faith, hope, and love remain-these three; and the greatest from these is love (my own literal translation).

88 Greek nyni (Adv)-adverb.

89 Cf. Congregation for the Doctrine of the Faith (1994), Katechizm Kościoła Katolickiego, Poznań: Pallottinum, no. 384.

90 Where true love and charity are, you will find living God there (my own literal translation).

91 We have been gathered together here by the love of Christ, let us rejoice in him and be joyful. Let us love God with true humility and let us love each other with pure hearts (my own literal translation). 
a pośrodku nas niech będzie Chrystus. ${ }^{92}$

Obyśmy oglądali Twoje oblicze, Chryste Boże, *

razem ze świętymi w chwale Twego Królestwa.

To będzie naszą radością czystą i bez granic *

przez nieskończone wieki wieków. Amen. ${ }^{93}$

\subsection{Historical-Critical Analysis}

The hymn Ubi caritas was written in order to unite the Church in the period of theological an doctrinal disputes. The original Latin hymn contains twelve stanzas, and each of them ends with the title chorus: Where charity (caritas) and love (amor) are, there God is. The author of that text is probably St. Paulinus of Aquileia (ca. 730-802). He was the person of trust to Charles the Great, who made him Patriarch of Aquileia. That saint bishop left behind numerous poems, from which four are included in the contemporary Liturgy of the Hours. Tradition connects the origins of Ubi caritas with the controversial Synod of Friuli in 797. During that Synod, the ancient controversies concerning the term Filioque were discussed. That controversy was among the reasons of the division of the Church into East and West in the 11th century. Bishop Paulinus anticipated the atmosphere of the meeting and wrote the liturgical hymn in order to remind theologians that it is impossible to do theology and fight for the purity of doctrine without mutual love and care for the unity of the Church ${ }^{94}$.

The hymn was first sung during the opening of the Synod of Cividale in 796. It was composed for a specific use: to sing during the common recreation of the monastery community. However, it was soon included in the liturgy of Maundy Thursday. Testimonies of the fact that the hymn was sung during mandatum already in the 10th century come from Monte Cassino. Its text was also published during the Eucharistic Congress in Udine in $1972^{95}$.

\subsection{Syntactic-Semantic Analysis}

The poem contains twelve stanzas of five verses each: after four verses there is one identical for all stanzas: "Ubi caritas ... ", which has the role of a chorus. In the Roman Missal, there are only three stanzas. In the original Latin text, each verse contains eight syllables with the rhythmic accent on the third syllable. Additionally, it is possible to see rhymes between two hemistichs, on the eighth and fourth syllable of a verse, perhaps introduced in order to help memorize the lyrics and the melody. Although the contemporary Roman Missal calls that composition a song ${ }^{96}$, the structure of the text resembles a hymn, which may be used in a responsorial way, dividing each verse between a cantor and the liturgical congregation ${ }^{97}$.

In order to strengthen his message, St. Paulinus placed his composition in the context of St. John's description of the Lord's Supper. The initial words of the hymn, "Zgromadziła nas tu w jedności miłość Pana" (We have been gathered together here by the love of Christ) take us to the Cenacle because there, having loved his own, Jesus has loved them to the end (John 13:1). Jesus builds the Church on that love, which means that he does not base her on himself, but on his relationship with his Father. He prays "that they may all be one. As you, Father, are in me and I am in you, may they also be in us" (Cf. John 17:21) ${ }^{98}$. The

92 Since we are all gathered together here, let us beware of what is dividing us. Let all resentments and arguments cease, and let Christ be in the center among us (my own literal translation).

93 Let us see your face, Christ God, together with the saints, in the glory of your Kingdom. That will be our joy, pure and boundless, for ages with no end. Amen (my own literal translation).

94 Cf. S. Nowak (2019), Ubi caritas et amor, in: https: / / www.liturgia.pl/ubi-caritas-et-amor (accessed on 20 May 2019).

95 Cf. P. Wiśniewski (2008), Śpiewy mandatum w polskich drukach muzyczno-liturgicznych XVIII wieku, Warszawa 2008, p. 76.

96 Cf. MR, p. 128.

97 Cf. P. Wiśniewski (2008), Śpiewy mandatum w polskich drukach muzyczno-liturgicznych XVIII wieku, Warszawa 2008, p. 77.

98 All the English quotations from the Bible used in this paper come from the New Revised Standard Version (1989). 
special character of that claim comes from the inclusion of the Church into the internal dialogue between the Son and the Father, which gives birth to the Holy Spirit ${ }^{99}$.

Patriarch Paulinus evokes St. Paul's words: If someone does not have love, he has lost everything and lives among dead dark shadows (Cf. 1 Corinthians 13:1), which reveals the emptiness and futility of living without amor and caritas. He urges us to seek unity in the community because that is what Jesus wants (Cf. Matthew 18:20) and in that way we can make him present among us.

In order to unite his disciples, Jesus continues to wash their feet. He reduces the power of God's love to that simple gesture of a servant and slave but does not diminish it at all. For that reason, we are invited to accept the words "Ubi caritas et amor, Deus ibi est" in faith. It is a call to put God's desire to be in the community into practice ${ }^{100}$.

\subsection{Pragmatic Analysis}

The analysis of the three stanzas included in the Roman Missal shows first of all a call for joy, which is rooted in the community of the Church. Praying in unity with others will lead us to joy if we care for the purity of our hearts, honesty, and humility, which constitutes the condition of good (joyful) relationships in the community (the first stanza).

The second stanza begins with a kind of warning concerning the possible divisions. The community of the Church is at risk of spiritual struggle and divisions. Thus, it is necessary to be alert (to be on guard) in order to prevent them. The tool for ending all arguments within the community is giving the central place to Christ in both one's personal life and the community life.

The third stanza provides us with a vision of heaven, which is the goal of our life. The text is a prayer, in which we ask God to be able to see him in his Kingdom. That will give us eternal joy "bez granic" (unbounded). The fullness of happiness will last forever-"na wieki wieków" (with no end).

\section{The Communion Antiphon}

To jest Ciało moje za was wydane; ten kielich jest Nowym Przymierzem we Krwi mojej. Czyńcie to, ile razy spożywać będziecie, na moja pamiątkę (Cf. 1 Corinthians 11:24-25). ${ }^{101}$

\subsection{Historical-Critical Analysis}

The fragment from 1 Corinthians 11:24-25, used in the Communion Antiphon, constitutes part of a longer text, titled "The Lord's Supper". Paul writes about issues that seem to be neglected in the first verses of that chapter, where he flatters Corinthians. The Apostle's judgment concerning liturgical meetings is as follows: we gather together, but instead of becoming better, we get worse. His further comments constitute a justification of that sad claim. Among Corinthians' vices that deserve condemnation, Paul lists first of all their selfishness, which is seen in their care for satisfying only their own hunger. In those circumstances, common meals not only cease to have anything in common with the Christian communitas, but quite the opposite, they bring shame to the Church and edification to no one ${ }^{102}$.

The teaching about the Eucharist (1 Corinthians 11:24-25) was received by Paul through the earlier oral tradition. The Apostle is one of the links in the chain reaching the Last Supper. That tradition includes the following truths:

Cf. S. Nowak (2019), Ubi caritas et amor, in: https: / /www.liturgia.pl/ubi-caritas-et-amor (accessed on 20 May 2019).

00 Cf. ibid.

101 This is my Body, given up for you; this chalice is the New Covenant in my Blood. Do this whenever you eat, in remembrance of me (my own literal translation).

102 Cf. Lech Stachowiak (1999), Komentarz praktyczny do Nowego Testamentu, vol. 2, pp. 143-44. 
- The Eucharistic feasts were initiated by Christ himself during the Last Supper, after which he was captured; in this way, Paul shows the close association between the Eucharist and Jesus' death;

- With time, the expression "breaking of bread" became a technical term used by the early Christians with reference to the Eucharistic feasts;

- The Eucharistic feasts are supposed to imitate the Last Supper together with its association with Jesus's death ${ }^{103}$.

The chalice mentioned in the antiphon (1 Corinthians 11:24) is actually the so-called third chalice drunk ceremonially during the second part of the Great Hallel. It is also called the Cup of Covenant because in the past, Moses took blood of the sacrificed oxen and said: "See the blood of the covenant that the LORD has made with you" (Exodus 24:8), and now, the New Covenant is sealed with the cup of Christ's Blood. The Greek term diathe $k \bar{e}^{104}$, which is used here, means not only a covenant, but also the last will or testament. While what happened at the foot of Mount Sion can only be called a covenant, in the analyzed text, both senses (covenant and testament) should be taken into account, as proven in Hebrews 9:15-28 105 .

Eating of matzo during Passover was usually interpreted as eating the bread of affliction, used by our ancestors during the times of Moses. Jesus explains that he is that bread $^{106}$.

\subsection{Syntactic-Semantic Analysis}

ANTIPHON: To jest Ciało moje za was wydane; ten kielich jest Nowym Przymierzem we Krwi mojej. Czyńcie to, ile razy ${ }^{\mathrm{a}}$ spożywać będziecie, na moja pamiątkę (Cf. 1 Corinthians 11:24-25). ${ }^{107}$

THE MILLENNIUM BIBLE: To jest Ciało moje za was [wydane ${ }^{\mathrm{A}}$ ]. Czyńcie to na moja pamiątkę! Podobnie, skończywszy wieczerzę , wział kielich , mówiąc: Ten kielich jest Nowym Przymierzem we Krwi mojej. Czyńcie to, ile razy a pić będziecie, na moja pamiątkę! $!^{108}$

THE LITERAL TRANSLATION: To jest moje Ciało, które za was [jest łamane ${ }^{\mathrm{A}}$. To czyńcie na moja pamiątkę. Podobnie i kielich po wieczerzy, mówiąc: Ten kielich to Nowe Przymierze we Krwi mojej; to czyńcie, ilekroć pijecie na moja pamiątke. ${ }^{109}$

The antiphon from the Roman Missal is a shortened version of the biblical text from MB, which includes Jesus' call, "czyńcie to ma moja pamiatke" (do this in remembrance of me), twice. In ANT, that call appears only once, at the end. In MB, we can find a remark that the words of the consecration of the Lord's Blood were uttered after the supper (MB: "skończywszy wieczerze" (having finished the supper); LT: "po wieczerzy"110 (after the supper)). MB contains the word "wydane" (given up), while in LT we read "jest łamane" (is being broken). ANT uses the expression "ile razy spożywać będziecie" (whenever you eat), but MB and LT read: "ile razy pić będziecie" (whenever you drink). All the versions of the text emphasize the fact that the covenant between God and people is "nowe"111 (new).

103 Cf. Lech Stachowiak (1999), Komentarz praktyczny do Nowego Testamentu, vol. 1, p. 146.

104 Greek diathēke (n_Nom Sg f)-noun, nominative case, singular number, feminine gender.

105 Cf. Lech Stachowiak (1999), Komentarz praktyczny do Nowego Testamentu, vol. 1, p. 146.

106 Cf. Craig S. Keener (2000), Komentarz historyczno-kulturowy do Nowego Testamentu, Warszawa, p. 364.

107 For the literal translation see footnote 91.

108 This is my Body, given up for you. Do this in remembrance of me! Similarly, having finished the supper, he took the chalice, saying: This chalice is the New Covenant in my Blood. Do this, whenever you drink, in remembrance of me! (my own literal translation).

109 This is my Body, which is being broken for you. Do this in remembrance of me. Similarly, also the chalice after the supper, saying: This chalice is the New Covenant in my Blood; do this, whenever you drink in remembrance of me (my own literal translation).

110 Greek meta to deipnēsai; Greek meta (Prep)-preposition.

111 Greek kainē (a_ Nom Sg f)-adjective, nominative case, singular number, feminine gender 


\subsection{Pragmatic Analysis}

The analysis of the biblical text reveals two calls to imitate the actions performed by Jesus in the Cenacle. We can see here a trace of the Antioch Tradition, in which the description of the origins of the Eucharist is longer and more precise, and also considered to be the oldest ${ }^{112}$. In the description, a special attention should be paid to the word "ilekroć" in LT or the expression "ile razy" in MB (whenever), which constitute an invitation to participate in the Eucharist as often as possible and consume not only the Passover lamb, but God alive, who "broke" or "gave up" his Body for us in order to give us "new" life.

\section{The Pange lingua Hymn-For the Transfer of the Most Blessed Sacrament}

Sław, języku, tajemnicę

Ciała i najdroższej Krwi,

Która, jako łask krynicę,

Wylał w czasie ziemskich dni

Ten, co Matkę miał Dziewicę,

Król narodów, godzien czci. ${ }^{113}$

Z Panny czystej narodzony,

Posłan zbawić ludzki ród,

Gdy po świecie, na wsze strony,

Ziarno słowa rzucił w lud,

Wtedy cudem niezgłębionym

Zamknął swej pielgrzymki trud. ${ }^{114}$

W noc ostatnia przy wieczerzy,

Z tymi, których braćmi zwał,

Pełniąc wszystko, jak należy,

Czego przepis prawny chciał,

Sam Dwunastu się powierzył

I za pokarm z rąk swych dał. ${ }^{115}$

Słowem więc, Wcielone Słowo,

Chleb zamienia w Ciało swe.

Wino Krwia jest Chrystusowa,

Darmo wzrok to widzieć chce.

Tylko wiara Bożą mowa

Pewność o tym w serca śle. ${ }^{116}$

Przed tak wielkim Sakramentem

Upadajmy wszyscy wraz,

Niech przed Nowym Testamentem

Starych praw ustapi czas.

112 In his description, St. Paul separates the consecration of the bread from the consecration of the wine, which takes place after the supper. Cf. B. Nadolski, Liturgika, vol. 4, p. 7.

113 Praise, the tongue, the mystery of the Body and the dearest Blood, which was spilled as the fount of graces, by the One whose Mother was the Virgin, the King of the Nations, worthy of praise (my own literal translation).

114 He was born of the pure Virgin, sent to save the human race; when he has cast the seed of the Word into people of all sides of the world, then he closed the effort of his pilgrimage with an unfathomable miracle (my own literal translation).

115 During the last night, at the supper with those he called his brothers, doing everything as it should be, fulfilling the requirements of the old law, he confided himself to the Twelve and gave them himself as food (my own literal translation).

116 Thus, the Incarnate Word changes the bread into his Body with his word. The wine is Christ's Blood, but the eyesight wants to see it in vain. Only faith, through God's speech, sends assurance of that into the hearts (my own literal translation). 
Co dla zmysłów niepojęte,

Niech dopełni wiara w nas. ${ }^{117}$

Bogu Ojcu i Synowi

Hołd po wszystkie nieśmy dni,

Niech podaje wiek wiekowi

Hymn triumfu, dzięki, czci,

A równemu im Duchowi

Niechaj wieczna chwała brzmi. ${ }^{118}$ Amen ${ }^{119}$.

\subsection{Historical and Linguistic Analysis}

St. Thomas Aquinas' famous hymn Pange lingua, which is an unsurpassed example of liturgical poetry of all time, exalts Christ's real presence in the Eucharist. The work is a prayer of praise, but it was composed in order to present the history of our salvation. After the mystery of the Body and Blood of God's Son, born of the Virgin, is evoked, Thomas presents the subsequent evangelical pictures of Jesus Christ: his ministry, the institution of the Eucharist at the end of his earthly pilgrimage, and his faithfulness to the Old Covenant. Next, moving to the description of the Most Blessed Sacrament, St. Thomas reminds us that we can see the Body and Blood of Christ in the Eucharistic appearances only through faith. The last two stanzas constitute a hymn of praise, sung during the exposition of the Holy Sacrament in the place of its preservation ${ }^{120}$.

In his teaching, St. Thomas considered the essence of the Eucharist very carefully, writing about its matter and form, as well as the way Christ is present in that sacrament. Those considerations, conducted with the precision and explicitness typical of scholasticism, were later adopted as the basis of the dogmatic claims of the Church's Magisterium, for instance, at the Council of Trent. Those considerations are excellently summarized by Mieczysław Gogacz, which can be seen in the following points:

1. Due to Christ's passion and the fact that his Body and Blood were separated during his passion, for consecration we use the bread and wine. Thus, in the Eucharist understood as a sacrifice, the Body and Blood are separated just like the bread and wine.

2. Due to the consequences of the Eucharist, we use the bread, which is something that nourishes the human body, and similarly, the Eucharistic Bread constitutes nourishment that gives people salvation. St. Thomas adds that while the Bread gives salvation to the body, the Wine we drink saves the soul. Since, according to the Old Testament, the living soul resides in the human blood, the blood is a symbol of the soul. That is another reason why the wine is used in the Mass separately. Thus, consuming the Body of Christ heals and saves our body. Drinking the Blood of Christ heals and saves our soul.

3. The bread ought to be consecrated because of the Church, since while the bread is composed of grains, the Church is made of all the faithful who love Christ. The bread perfectly represents the structure of the Church. We consume the Body and Blood of Christ as the bread and wine in order to be united with the Church and with Christ. The Eucharist builds that unity of the Church and leads us deeper into Christ ${ }^{121}$.

117 Let us fall down before such a great Sacrament; let the times of the old laws yield before the New Testament. Let faith complete in us what is incomprehensible to our senses (my own literal translation).

118 Let us pay tribute to God the Father and the Son day by day; let each age pass to the next age the hymn of triumph, gratitude, and praise, and let eternal praise be heard to the Spirit, who is equal with both (my own literal translation).

119 The Polish translation comes from: Gaudeamus. Łaciński śpiewnik mszalny, ed. Wojciech Kądziela (2006), Warszawa 2006, pp. 228-29; Cf. also MR, pp. 131-32.

120 A. Andrzejuk (2019), Chrystocentryczny charakter Eucharystii w teologii św. Tomasza z Akwinu, in: www.katedra.uksw.edu.pl, pp. 6-7, 20 May.

121 Cf. M. Gogacz (1988), Największa jest miłość. Rozważania rekolekcyjne, Warszawa-Kraków, pp. 100-1. 


\subsection{Pragmatic Analysis}

The hymn is sung during the procession and as every procession chant it is a call to look at one's life as if it were a way (procession). During the way we are invited to praise God, who, after his death and resurrection, remained with us in his Body and Blood, and has become our food. God is worthy of praise (the first stanza).

Stanzas two, three, and four include an invitation to be grateful for the history of Christ's life, who came to the world to save us. Noticing that grace of salvation is possible only with the help of God-our reason and senses ("wzrok" (eyesight)) are unable to see all that God has done for us.

Stanzas five and six, which are conventionally sung after the place of repose has been reached, call for adoration on one's knees in order to strengthen one's faith, which is necessary to avoid the obscuration of the richness of that grace by our senses. Additionally, we are invited to proclaim the Gospel ("niech podaje wiek wiekowi" (let each age pass to the next age)) because such a great grace ought not to be kept only for ourselves.

\section{Conclusions}

The analysis of the Polish antiphons, the song, and the hymn from the Mass of the Lord's Supper reveals that these texts come from both biblical and non-biblical sources. The biblical sources include the following fragments:

1. John 13:4-8, 14, 15, 34, 35, 1 Corinthians 11:24, 25, 1 Corinthians 13:13, 1 John 2; 3; 4 (this source of Ubi caritas is provided in the Missal of Pius V). The non-biblical sources include:

2. St. Thomas Aquinas' hymn Pange lingua, St. Paulinus of Aquileia's text of Ubi caritas, based on 1 John $2 ; 3 ; 4$.

The leading thought in all those analyzed texts is Jesus' unconditioned love for man, which is expressed first in the gesture of the washing of feet, and then confirmed in the sign of the Cross. Jesus goes beyond the conventional Jewish customs and gives radical signs, which are supposed to show explicitly that all his followers are invited to imitate his love, surpassing all cultural standards. We are invited to love in the way expressed by the Greek word agape-to love in a perfect way.

Christ does not leave us alone with that new commandment of love, which is based on his own example. He helps us with his presence in the Most Blessed Sacrament. He becomes food that protects the whole community of the Church from her breakup (Cf. Ubi caritas) and gives us strength to last.

In the texts of the Lord's Supper we are called to praise God (hymn Pange lingua) because he is the only one deserving praise. We ought not to forget about the adoration of the Blessed Sacrament (the stanza beginning with the verse Tantum ergo) because without it our senses are unable to comprehend the great mystery of faith, which was revealed in the Cenacle.

The comparison of the texts from the Polish edition of the Roman Missal and the Greek original text, as well as the Millennium Bible shows that the Polish Missal does not always express its full and deepest sense. The conducted analysis allows us to assess critically the following translations:

- The Entrance Antiphon-“chlubimy się" (we boast)—-the plural number is unjustified;

- The first antiphon-the expression "złożył szaty" (he folded his robes) is missing;

- The second antiphon-Peter's answer is too gentle; the exclamation "Nie, nigdy!" (Never, ever!) was changed to a polite question "Ty chcesz mi umyć nogi?" (You want to wash my legs?);

- The third antiphon-the word "stopy" (feet) was changed to "nogi" (legs), which modified and simplified the sense of the text;

The Communion Antiphon-the word "łamane" (broken) was replaced with the word "wydane" (given up), which mitigates the sense of the whole sentence. 
In the context of the above analysis, it seems that the current Polish translation of the Roman Missal tends to avoid radical and strong expressions, mitigating the dramaturgy of the events from the Cenacle and Golgotha.

In the future translations it would be a good idea to return to the bolder and more authentic senses, using, as the Instruction ${ }^{122}$ says, the original Greek text of the Bible.

We wish to finish our considerations with John Paul II's words from his Letter Dominicae Cenae of 1980:

"In fact, Christian life is expressed in the fulfilling of the greatest commandment, that is to say, in the love of God and neighbor, and this love finds its source in the blessed Sacrament, which is commonly called the sacrament of love. ( ...) The authentic sense of the Eucharist becomes of itself the school of active love for neighbor. We know that this is the true and full order of love that the Lord has taught us: «By this love you have for one another, everyone will know that you are my disciples» (John 13:15)"123.

Funding: This research was funded by Uniwersytet Śląski w Katowicach, ul. Bankowa 12, 40-007 Katowice, NIP 634-019-71-34, University program “Inicjatywa Doskonałości Badawczej”.

Conflicts of Interest: The author declares no conflict of interest.

\section{References}

\section{Primary References}

Biblia Tysiaclecia. Pismo Święte Starego i Nowego Testamentu. Poznań: ed. V. 2015.

New Revised Standard Version. 1989. Available online: https://www.biblegateway.com/versions/New-Revised-Standard-VersionNRSV-Bible/ (accessed on 1 December 2020).

\section{Secondary References}

Andrzejuk, Artur. 2019. Chrystocentryczny Charakter Eucharystii w Teologii św. Tomasza z Akwinu. pp. 6-7. Available online: www.katedra.uksw.edu.pl (accessed on 1 December 2020).

Congregatio de Cultu Divino et Disciplina Sacramentorum. 2016. Dekret. In missa in cena Domini. Available online: http://www. vatican.va/roman_curia/congregations /ccdds /documents/rc_con_ccdds_doc_20160106_decreto-lavanda-piedi_en.html (accessed on 1 December 2020).

Congregation for Divine Worship and the Discipline of the Sacraments. 2001. Liturgiam Authenticam. Available online: https://www. vatican.va/roman_curia/congregations /ccdds/documents/rc_con_ccdds_doc_20010507_liturgiam-authenticam_en.html (accessed on 1 December 2020).

Congregation for the Doctrine of the Faith. 1994. Katechizm Kościoła Katolickiego. Poznań: Pallottinum.

Czerski, Janusz. 1997. Metody interpretacji Nowego Testamentu: Opolska Biblioteka Teologiczna 21. Opole: WTUO, p. 69.

Czerski, Janusz. 2012. The Methodology of the New Testament. Opole: WTUO, p. 89.

Dańczak, Andrzej. 2019. Locutio Mundi-Znaczenie i Zakres Określenia “Sakramentalność Świata”. Studia Gdańskie $25: 15$.

Durak, Adam. 1999. Metody Hermeneutyczne w Twórczości Homiletycznej. Seminare. Poszukiwania naukowe 15: 78.

Gogacz, Mieczysław. 1988. Największa Jest Miłość. Rozważania Rekolekcyjne. Warszawa and Kraków: Michalineum, pp. 100-1.

Holy See. 2013. Mszał Rzymski dla Diecezji Polskich. Poznań: Pallotinum, pp. 126-32.

John Paul II. 1980. Dominicae Cenae. no. 5-6. Available online: http://www.vatican.va/content/john-paul-ii/en/letters/1980 /documents/hf_jp-ii_let_19800224_dominicae-cenae.html (accessed on 1 December 2020).

John Paul II. 2004. Apostolic letter Mane nobiscum Domine. no. 17. Available online: http:/ /www.vatican.va/content/john-paul-ii/ en/apost_letters/2004/documents/hf_jp-ii_apl_20041008_mane-nobiscum-domine.html (accessed on 1 December 2020).

Kądziela, Wojciech. 2006. Gaudeamus. Łaciński Śpiewnik Mszalny. Edited by Wojciech Kądziela. Warszawa: Wydawnictwo Sióstr Loretanek, pp. 228-29.

Keener, Craig S. 2000. Komentarz Historyczno-Kulturowy do Nowego Testamentu. Edited by Craig S. Keener. Warszawa: Vocatio, p. 215.

Nadolski, Bogusław. 2011. Liturgika-vol. 4: Eucharystia. Poznań: Pallotinum, p. 3.

Nowak, Stanisław. 2019. Ubi Caritas et Amor. Available online: https://www.liturgia.pl/ubi-caritas-et-amor (accessed on 1 December 2020).

Okure, Teresa. 2001. Ewangelia Według św. Jana: Międzynarodowy Komentarz do Pisma Świętego. Edited by Waldemar Chrostowski. Warszawa: Verbinum, p. 1349.

122 Congregation for Divine Worship and the Discipline of the Sacraments (2001) Liturgiam authenticam (28.032001), 24.

123 John Paul II (1980), Dominicae Cenae, 24 February, no. 5-6. 
Popowski Remigiusz, Wojciechowski Michał. 1994. Grecko-Polski Nowy Testament. Translated by Remigiusz Popowski, and Michał Wojciechowski. Warszawa: Vocatio.

Sobeczko, Helmut Jan. 2007. Pluralizm Metod Stosowanych w Nauce o Liturgii. Studia Nauk Teologicznych 2: 251-59.

Stachowiak, Lech. 1975. Ewangelia Według św. Jana. Wstęp-Przekład z Oryginału-Komentarz. Edited by Lech Stachowiak. Poznań-Kraków: Pallotinum, pp. 300-1.

Stachowiak, Lech. 1998. Komentarz Praktyczny do Nowego Testamentu-vol. 1. Edited by Lech Stachowiak. Poznań and Kraków: Pallottinum, p. 152.

Stachowiak, Lech. 1999. Komentarz Praktyczny do Nowego Testamentu-vol. 2. Edited by Lech Stachowiak. Poznań and Kraków: Pallottinum, p. 245.

Szymanek, Edward. 1978. List do Galatów. Wstęp-Przekład z Oryginatu-Komentarz. Edited by Edward Szymanek. Poznań and Warszawa: Pallottinum, p. 117.

Tamez, Elsa. 2001. List do Galatów: Międzynarodowy Komentarz do Pisma Świętego. Edited by Waldemar Chrostowski. Warszawa: Verbinum, p. 1520.

van der Watt, Jan. 2017. The Meaning of Jesus Washinag the Feet of His Disciples (John 13). Neotestamentica 51: 25-40. [CrossRef]

Wiśniewski, Piotr. 2008. Śpiewy Mandatum w Polskich Drukach Muzyczno-Liturgicznych XVIII Wieku. Warszawa: Uniwersytetu Kardynała Stefana Wyszýnskiego, p. 76.

Żądło, Andrzej. 2002. Eklejzalny Wymiar Kolekt Adwentu w Mszale Rzymskim Pawła VI. Studium Teologiczno-Lingwistyczne. Kraków: Instytut Teologiczny Księży Misjonarzy, pp. 9-14. 